\section{B A Institute of \\ YK Business Administration \\ 六下 \\ Karachi \\ Leadership and Ideas for Tomorrow}

Business Review

Volume 5 Issue 2 July-December 2010

$7-1-2010$

\title{
Determinants of Foreign Direct Investment in services sector of Pakistan: An econometrics approach
}

\author{
Muhammad Zahid Awan \\ Gomal University, D. I. Khan, Pakistan \\ Khair uz Zaman \\ Gomal University, D. I. Khan, Pakistan \\ Bakhtiar Khan \\ Gomal University, D. I. Khan, Pakistan
}

Follow this and additional works at: https://ir.iba.edu.pk/businessreview

Part of the Econometrics Commons, and the Finance and Financial Management Commons

\section{c) (7)}

This work is licensed under a Creative Commons Attribution 4.0 International License.

\section{Recommended Citation}

Awan, M. Z., Zaman, K., \& Khan, B. (2010). Determinants of Foreign Direct Investment in services sector of Pakistan: An econometrics approach. Business Review, 5(2), 167-180. Retrieved from https://doi.org/ 10.54784/1990-6587.1251

This article is brought to you by iRepository for open access under the Creative Commons Attribution 4.0 License and is available at https://ir.iba.edu.pk/businessreview/vol5/iss2/11. For more information, please contact irepository@iba.edu.pk. 


\title{
DISCUSSION
}

\section{DETERMINANTS OF FOREIGN DIRECT INVESTMENT IN SERVICES SECTOR OF PAKISTAN: An Econometric Approach}

\author{
Muhammad Zahid Awan \\ Gomal University, D. I. Khan, Pakistan. \\ Khair uz Zaman \\ Gomal University, D. I. Khan, Pakistan. \\ Bakhtiar Khan \\ Gomal University, D. I. Khan, Pakistan.
}

\begin{abstract}
This study examines the key determinants of FDI inflows in Services sector of Pakistan, using time series data (quarterly) for the period of 1996Q1-2008Q4. To check the sationarity of the data, ADF test has been applied. Co-integration and Error Correction Model (ECM) is used for estimation of the data. This study found that Gross Domestic Fixed Capital formation (GDFCF), Inflation Rate(INF), Current Account Balance (CAB), Exchange Rate (ER), and Per Capita Income (PC) are main factors of FDI inflows in services sector of Pakistan. This study reveals that GDFCF, INF and $P C$ are found statistically significant with positive signs. CAB and ER are also statistically significant with negative sign. While, trade openness (TO) is found statistically insignificant but with negative sign.
\end{abstract}

Keywords: FDI, Services Sector, Econometric Model, GDFCF, Per capita Income, Inflation Rate, Exchange Rate, Pakistan.

\section{INTRODUCTION}

It is generally perceived by the countries which are rapidly making progress in economic development that FDI has proved to be a substantial booster for economic uplift of these countries. According to these countries, different types of vacuums are covered. These are mainly investment vacuum which takes into account investment shortage and fills it. Secondly it is foreign exchange gap which with the help of FDI meets the investment requirements and ultimately becomes a major source of earnings through export. At last but not least, it bridges the gap between tax and revenue ratio as the additional investment provides a boost to employment, industry, agriculture and thus making revenue from these sources in shape of tax.

Over the last two decades, Government of Pakistan (GOP) has initiated marketbased economic reform policies. To initiate foreign investment, GOP has offered multiple incentives to foreign investors including relaxation in trade, fiscal incentives, tax concession or exemption, credit facilities, tariff reduction and foreign exchange control 
https://ir.iba.edu.pk/businessreview/vol5/iss2/11

DOI: https://doi.org/10.54784/1990-6587.1251

Business Review - Volume 5 Number 2

July - December 2010

as well (Khan, 1999). In 1990's, GOP has opened its doors for foreign investors in agriculture, telecommunication, energy, and services sectors by relaxing its policies. Unfortunately, Pakistan could not attract considerable share of FDI as compared to other developing countries due to political uncertainties , and inconsistent policies. However, during 1990's, FDI inflow was revealed incredible growth over time.

Recently, GOP has adopted liberal investment policy to induce foreign investors in the services sector, especially in the telecommunication sector. In this regard, GOP has minimized the foreign equity upto US\$ 0.5 million in 2000 for all the sectors of services industry. Further, GOP has reduced it to US\$ 0.15 million in 2004. Another attraction for foreign investors in the services sector of Pakistan is that GOP has allowed them to own $100 \%$ equity and they can repatriate their $100 \%$ profit to home country.

Main objective of conducting this study is to examine the main determinants of FDI in Services sector of Pakistan which influence FDI inflows in aforesaid sector of Pakistan. This study is organized as follows:

Section II reviews the literature, section III describes research methodology and data sources, section IV discusses regression results and analysis, and section V deals with conclusion.

\section{LITERATURE REVIEW}

There are limited studies that have discussed the issue and importance of FDI relating to the services sector in Pakistan. Let we take the review of few important studies.

Studies such as Miller \& Parkhe (1998); Nigh et al (1986); Goldberg and Johnson (1990), FDI inflows in total and FDI in banking sector are positively related. Moshiran (1997) also examined impact of exchange rate on FDI inflows in the host country and found that exchange rate of host country is strongly significant to FDI inflows, particularly in services sector. He argued that appreciation in host country's currency leads to increase FDI inflows in Insurance sector and found that rate of return is significant to FDI in financial services. Whereas, Yamori (1998) explored that in long run, exchange rate volatility does not affect FDI inflows considerably in financial services and his study does not support the association between rate of return and FDI inflows in financial sector.

Rubio \& Simon (1994) conducted study by using annual time series data for the period of 1964-89 This study used co-integration techniques for estimation. Results indicate that long run association exists between FDI, real GDP, inflation rate, trade

168 
https://ir.iba.edu.pk/businessreview/vol5/iss2/11

DOI: https://doi.org/10.54784/1990-6587.1251

Business Review - Volume 5 Number 2

July - December 2010

barriers and foreign capital stock. Further, they found that main determinants of FDI in manufacturing and Non-manufacturing sectors are almost same rather in total FDI. Other studies such as Macedo (2000) and Pinheiro (1996) in Brazil, Campbell et al (1998) in Sub-Saharn Africa, Appiah (2001) in Ghana, Andreasson (1998) in Mozambique, Due et al (2002), Temu et al (1998) examined commodity producing sector and services sector firms and they argued that efficiency and productivity of all the firms improved after privatization.

Akhtar (2001) conducted study to examine the determinants of extension of foreign banks in Pakistan and found that vital determinants of existence and development of foreign banks in Pakistan are market size, diversification of risk, profitability, trade financing and so on.

Ivar and Villinger (2008) conducted study to analyze the determinants of FDI in services sector of host economies. They used data of 57 countries for the period of 1989-2000. They found that institutional climate and democracy are more significant for FDI in services sector but trade openness does not impact significantly because service sector is 'Marketing-seeking" FDI. They also found strong correlation between $\backslash$ FDI in manufacturing sector and FDI in Producer's Services Sector'.

\section{RESEARCH METHODOLOGY AND DATA SOURCES} model:

After reviewing the literature, this study is based on the following econometric

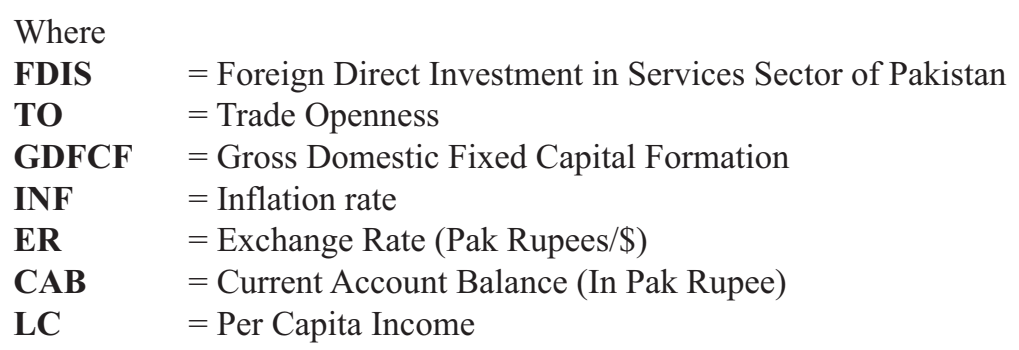

It is hypothesized that 
https://ir.iba.edu.pk/businessreview/vol5/iss2/11

DOI: https://doi.org/10.54784/1990-6587.1251

Business Review - Volume 5 Number 2

July - December 2010

\section{DETAIL OF VARIABLES}

FDIS is used as a dependent variable. Services sector includes Transport and communication, storage, trade, financial services, social services, and tourism etc. It has been observed, that services sector has been growing at a faster rate than commodity producing sector of the Pakistan since 2000. In this study, we have analyzed the impacts of various macroeconomic variables on FDI in services Sector. Data for this variable has been taken from economic survey of Pakistan, web site of Board of Investment of Pakistan (BOI), and various issues of statistical bulletins of State Bank of Pakistan. We have constructed RFDIS in Pak rupee.

\section{Following variables have been used as independent variables:}

Trade Openness (TO), Gross Domestic Fixed Capital Formation (GDFCF), Inflation Rate (INF), Exchange Rate (ER), Current Account Balance (CAB), and Per Capita Income (PC) are taken as independent variables. All variables are measured in terms of Pak rupee. Data for this variable has been taken from various issues of economic survey of Pakistan, web site of Board of Investment of Pakistan (BOI), and various issues of statistical bulletins of State Bank of Pakistan.

Trade Openness is sum of Exports and Imports of Pakistan in each year and it is used to measure the degree of openness.

Time series data (quarterly) has been used for the period of 1996-2008. The study largely depends on secondary data sources originally collected by various organizations. Data have been gathered from World Investment Reports (WIR), various issues of Economic Surveys of Pakistan (1999-2000, 2001-02, 2003-04, 2005-06, 20062007, 2007-2008 and 2008-2009), Board of Investment (BOI), Statistical Year Book 2005, Various issues of Statistical Bulletin of State Bank of Pakistan For the analysis of data, Micro Fit \#4.0(Interactive Econometric Analysis) has been used.

To investigate the major economic determinants of FDI in Services Sector of Pakistan, time series data (quarterly) have been used, covering the period for 19962008. Various summary statistics, correlation among variables, results of ADF test, and regression results are given in tables 1,2, and 3(see Appendix)

\section{REGRESSION RESULTS}

The main purpose of this section is to formulate the model to investigate the affect of aforesaid variables on the FDI in services sector of Pakistan. The variables selected which influence FDI inflows in services sector of Pakistan are: Degree of trade 
https://ir.iba.edu.pk/businessreview/vol5/iss2/11

DOI: https://doi.org/10.54784/1990-6587.1251

Business Review - Volume 5 Number 2

July - December 2010

Openness, Gross domestic Fixed Capital Formation, current account balance. Inflation rate, exchange rate, and per capita income. Usually, time series data illustrates the nonstationarity and provide ambiguous results. First of all, we need to check the existence of unit root in order to eliminate the ambiguity in the results. Second step is to find out order of integration of all the datasets. So, Augmented-Dickey-Fuller (ADF) test was used for unit roots to determine all the variables in model are integrated in the same order. ADF test shows that all variables have stationarity in the levels of $95 \%$ critical values without trend. All variables are in first difference. Thus from the Unit Root test we conclude that all of the variables are integrated of order 1(1). (see table 3 ) We have used FDIS as a dependent variable in our study and used time series data covering the period of 1996-2008 (Quarterly). Table 4 shows the regression results of our model.

Results show that degree of trade openness (TO) is statistically insignificant but with positive sign. Similarly, Gross domestic fixed capital formation is also found statistically insignificant with positive sign.

Study reveals that inflation rate (INF) is statistically significant at $10 \%$ level of significance with positive sign. High inflation rate leads to rise the price level which, in turn, increase the profit margin of the investors. So our study indicates that high inflation rate attracts foreign investors in services sector of Pakistan. Current Account Balance (CAB) is also found highly significant at the level of $1 \%$ with negative sign, which indicates that improvement in balance of payment builds up the confidence of foreign investors in service sector and increase the FDI in this sector. Exchange rate (ER) is one of the most important variables in our study and found statistically significant at $5 \%$ level of significance with expected sign. Per Capita Income (PC) also some matters in our study and found highly significant at the level of $1 \%$ with positive sign. Per capita income reflects the standard of living of the people of host countries and their buying power. Our results show that high standard of living and high buying power creates the wide market which leads to attract foreign investment in services sector.

R2 and adjusted R2 are 0.90983 and 0.89842 respectively whereas D. Wstatistics is 1.6517. (See table 4 in annexure)

\section{ESTIMATION OF ERROR CORRECTION MODEL (ECM)}

An Error Correction Model (ECM) has been applied to find out the short run dynamics of this model. Now our model is estimated in the following equation: 
https://ir.iba.edu.pk/businessreview/vol5/iss2/11

DOI: https://doi.org/10.54784/1990-6587.1251

Business Review - Volume 5 Number 2

July - December 2010

Where $\mathrm{r}(-1)$ represents error correcting term.

The results of ECM of FDI in service sectors of Pakistan are given in table 5.

\section{REGRESSION RESULTS}

Result indicates that all variables are found statistically significant with required sign except degree of trade openness (TO). By applying ECM, GDP is found statistically significant at $1 \%$ level of significance with positive sign whereas degree of trade openness is still insignificant. R2 and adjusted R2 were 0.56970 and 0.49623 respectively and D.W-statistics has improved upto 1.9441 (means no serial correlation).

After applying ECM, all variables were significant with the required sign except trade openness. $\mathrm{R}$ (Residual) is also found statistically significant at the level of $1 \%$ with positive sign and speed of adjust is almost $50 \%$.

Tests for structural stability based on Brown et al (1975: cited in Pesaran and Pesaran , 1997) suggests that at 5\% level of confidence, there is insufficient evidence to reject null hypothesis, that model is well specified (see figure 3 (a) and 3 (b) in annexure).

\section{CONCLUSION}

In Pakistan, Services sector has become largest productive sector since 2001. The prominent contribution of FDI inflows into services sector is the transfer of technology which leads to boost up economic development and economic growth as well. It is worth mentioning that FDI inflows into services sector provide transfer of skill and advance technology but also increase the employment level. The motivation of this study is to investigate the key determinants of FDI inflows in Services Sector of Pakistan using time series data (quarterly) for the period of 1996Q1-2008Q4. This research paper points out how different variables impact on FDI inflows in aforesaid sector of Pakistan. To investigate impact of independent variables on FDI in Services Sector of Pakistan, Co-integration and Error Correction Model (ECM) has been used. FDI inflows in Services sector in Pakistan is taken as a dependents variables whereas degree of trade openness, inflation rate, current account balance, gross domestic fixed capital formation, exchange rate and per capita income are taken as independent variables. This study shows that all the variables are found statistically significant with positive sign except degree of trade openness. This indicates that FDI in service sector increases with the rise in capita income and appreciation in home country currency. With the increase in capital formation and developed infrastructure attract more foreign investment. Improvement in balance of payment encourages foreign investors to make heavy investment to meet rising demand of the growing population in services sector of 
https://ir.iba.edu.pk/businessreview/vol5/iss2/11

DOI: https://doi.org/10.54784/1990-6587.1251

Business Review - Volume 5 Number 2

July - December 2010

Pakistan. This study concludes that that gross Domestic Capital Formation, Current Account Balance, Inflation Rate, Exchange rate, and per capita income, have favorable impact on motivating the FDI in services sector of Pakistan.

\section{BIBLIOGRAPHY}

Akhtar., M. H. (2001). "Multinational Banking in Pakistan". Global Business Andreasson , Bo. (1998), "Privatization in Sub-Saharan Africa: Has It Worked and What Lesson Can Be Learnt?" Swedish Development advisers. Gothenburg, Sweden.

Appiah -Kubi,K, (2001) "State Owned Enterprises and Privatization in Ghana". Ashfaque H. Khan and Yun-Hwan Kim (1999), "Foreign Direct Investment: Policy Issues and Operational Implications", EDRC Report series No. 66.

Bajo-Rubio .O; Sosvilla-Rivero. S. (1994), “An Econometric Analysis of Foreign Direct Investment in Spain 1964-89”.Southern Economic Journal, Vol. 61, No.1, 104-120.

Brown R.L., Durbin J. and Evans J. M. (1975). "Techniques for testing the Constancy of Regression Relations overtime (with discussion)", Journal of the Royal Statistical Society B, vol. 37, pp: 149-192.

Caves, R (1971), "International Corporations; the industrial economics of foreign investments", Economica, Vol. 38, pp.1-27.

Demirhan, E., and Masca, M. (2008),'Determinants of Foreign Direct Investment Flows to Developing Countries: A Cross-Sectional Analysis". Prague Economic Papers, 4, 356-369.

Due, Jean M., Andrew Temu (2002), "Changes in Employment by Gender and Business Organization in Newly Privatized Companies in Tanzania". Canadian Journal of Development Studies. 23(2). PP 317-333

Imad A. Moosa, Baly A. Cardak (2006), "The Determinants of FDI: an extreme bound analysis". Journal of Multinational Financial Management 16 (2006) 199-211.

Ivar. K, Espen V. (2008). "Determinants of Foreign Direct Investment in Services" European Journal of Political Economy 24 (2008), 514-533. 
Kok, R., and Ersoy, B.A. (2009). "Analysis of FDI in Developing Countries". International Journal of Social Economics, 36(1/2), 105-123.

Kumar. R (2003), "Changing Role of the Public Sector in the Promotion of FDI”. Asia-Pacific Journal, Vol.10, No.2.

Kyaw. S (2003), "Foreign Direct Investment to Developing Countries in the Globalised World". Paper presented at the DSA conference 2003, University of Strathclyde, Glasgow. 10-12 September, 2003

Macedo, Roberto (2000), " Privatization and distribution of assets income in Brazil”. Workig Paper 14. Carnegie Endowment for International Peace, Washington,D.C.

Oum,T.H. and Zhang,Y.(1995), "Competition and allocative efficiency: The case of US Telephone Industry", Review of Economics and Statistics, vol. 77 , pp.82-96.

Pesaran, M.H. and Pesaran. B (1997). Working woth Microfit 4.0: Interactive Econometric Analysis, Oxford, Oxford University Press, pp: 117.

Pinheiro, Armando C. (1996) “Impactos Microeconomicos Da Privatizacao No Brasil” Pesquiae Planejamento Economico 26(3): pp. 357-398

Statistical Year Book of Pakistan 2005

Tsai, P. (1994), "Determinants of Foreign Direct Investment and its impact on economic Growth”. Journal of Economic Development, 19(19), 137-163.

Various issues of Economic Survey of Pakistan (2000-2001, 2004-2005, 20082009)

World Bank Reports

World Investment Report, 2005, 2006, 2007, 2008, and 2009.

Yousaf. M.M, Hussain.Z and Ahmad,N (2008), "Economic Evaluation of Foreign Direct Investment in Pakistan", "Pakistan Economic and Social Review, Volume 46, No.1 (Summer 2008), pp. 35-56. 


\section{ANNEXURE}

Table 1. DESCRIPTIVE STATISTICS (Sample period: 1996Q1- 2008Q4)

\begin{tabular}{|l|l|l|l|l|l|l|l|}
\hline Variable(s) & FDIS & TO & GDFCF & INF & ER & CAB & PC \\
\hline Maximum & 61302.9 & 1384407 & 248790.1 & 2.7657 & 181.1000 & 256038.4 & 34800.0 \\
\hline Minimum & 364.0000 & $195986 . .4$ & 22983.3 & 2.4660 & 65.5000 & 5663.8 & 15320.0 \\
\hline Mean & 16243.1 & 423872.8 & 139867.1 & 2.5903 & 108.1258 & 53254.0 & 26663.3 \\
\hline Std. Deviation & 197867 & 263140.9 & 83893.1 & 0.10013 & 24.5335 & 60123.7 & 6427.0 \\
\hline Coef: of Variation & 1.2182 & 0.62080 & 0.59981 & 0.038656 & 0.22690 & 1.1290 & 0.24104 \\
\hline
\end{tabular}

Source: Calculated by author

Table 2. ESTIMATED CORRELATION BETWEEN FDI AND OTHER VARIABLES

\begin{tabular}{|l|l|l|l|l|l|l|l|}
\hline Variables & L FDIS & LTO & LGDFCF & LINF & LCAB & LER & LPC \\
\hline L FDIS & 1.0000 & & & & & & \\
\hline L TO & 0.94514 & 1.0000 & & & & & \\
\hline L GDFCF & 0.80681 & 0.81183 & 1.0000 & & & & \\
\hline L INF & 0.91736 & 0.95889 & 0.83344 & 1.0000 & & & \\
\hline L CAB & 0.77452 & 0.76230 & 0.41978 & 0.69173 & 1.0000 & & \\
\hline L ER & 0.68255 & 0.73613 & 0.89406 & 0.84197 & 0.28529 & 1.0000 & \\
\hline L PC & 0.86799 & 0.87692 & 0.94933 & 0.93487 & 0.49951 & 0.94555 & 1.0000 \\
\hline
\end{tabular}

Source: Calculated by author

Table 3. RESULTS OF ADF TEST

\begin{tabular}{|l|l|l|l|l|}
\hline Variables & Level/Difference & Without trend & With trend & Order of Integration \\
\hline LFDIS & Level & 0.59995 & -2.0526 & \\
& First Difference & -7.3334 & -7.2585 & $\mathrm{I}(1)$ \\
\hline \multirow{2}{*}{ LTO } & Level & 3.0578 & 0.27365 & \\
& First Difference & -4.5686 & -5.5008 & $\mathrm{I}(1)$ \\
\hline \multirow{2}{*}{ LGDFCF } & Level & -1.5647 & -1.7836 & \\
& First Difference & -6.8579 & -6.8734 & $\mathrm{I}(1)$ \\
\hline \multirow{2}{*}{ LINF } & Level & 2.3693 & 0.84956 & \\
& First Difference & -3.2852 & -3.6865 & $\mathrm{I}(1)$ \\
\hline \multirow{2}{*}{ LCAB } & Level & -0.29255 & -1.7331 & \\
& First Difference & -6.3543 & -6.4955 & $\mathrm{I}(1)$ \\
\hline \multirow{2}{*}{ LER } & Level & -0.095565 & -0.91627 & \\
& First Difference & -5.1831 & -5.1342 & $\mathrm{I}(1)$ \\
\hline \multirow{2}{*}{ LPC } & Level & -2.0337 & -1.2485 & \\
& First Difference & -6.8778 & -7.3206 & $\mathrm{I}(1)$ \\
\hline
\end{tabular}

95\% critical value for ADF Statistics for all variables: -2.9256 (without trend) and -3.5088 (with trend)

Source: Calculated by author 
https://ir.iba.edu.pk/businessreview/vol5/iss2/11

DOI: https://doi.org/10.54784/1990-6587.1251

Business Review - Volume 5 Number 2

July - December 2010

Table 4 FDI in Services Sector(LRFDIS)DEPENDENT VARIABLE REGRESSION RESULTS (1996Q1- 2008Q4)

\begin{tabular}{|l|l|l|c|}
\hline Variables & Coefficient & t-statistics & Probability \\
\hline Constant term & 0.16632 & 3.3101 & 0.000 \\
\hline L TO & 0.51250 & 1.3891 & 0.178 \\
\hline L GDFCF & 0.032189 & 1.5181 & 0.320 \\
\hline L INF & 2.2215 & 1.7091 & $0.095^{* * *}$ \\
\hline L CAB & -0.43350 & -4.1653 & $0.000^{*}$ \\
\hline L ER & -4.8040 & -3.5356 & $0.001^{*}$ \\
\hline L PC & 7.0670 & 3.3237 & $0.002^{* *}$ \\
\hline F-Statistics & 11.8253 & & $0.000^{*}$ \\
\hline R $^{2}$ & 0.90983 & & \\
\hline Adjusted R & & \\
\hline D.W & 0.89842 & & \\
\hline No of Observations & 1.6517 & & \\
\hline
\end{tabular}

$* * *, * *, *$ indicates $10 \%, 5 \%$, and $1 \%$ level of significance respectively.

Source: Calculated by author

Table 5 ECM RESULTS

\begin{tabular}{|l|l|ll|}
\hline Variables & Coefficient & \multicolumn{2}{|l|}{$\begin{array}{l}\text { t-Statistics } \\
\text { (Probability) }\end{array}$} \\
\hline Constant term & 0.17049 & 3.3124 & $(0.002)$ \\
\hline DLTO & 0.87038 & 1.1185 & $(0.270)$ \\
\hline DL GDFCF & 0.0 .64820 & 2.6631 & $(0.011)^{*}$ \\
\hline DL INF & 2.5133 & 1.8589 & $(0.070)^{* *}$ \\
\hline DL CAB & -0.34219 & -3.0654 & $(0.004)^{* *}$ \\
\hline DLER & -4.8619 & -3.5243 & $(0.001)^{*}$ \\
\hline DL PC & 4.4809 & 2.2375 & $(0.031)^{* *}$ \\
\hline R(-1) & 0.501080 & 3.32019 & $(0.001)^{*}$ \\
\hline F-Statistics F(6,45) & 7.7546 & $(0.000)^{*}$ & \\
\hline$R^{2}$ & 0.56970 & & \\
\hline Adjusted R & & \\
\hline D.W & 0.49623 & & \\
\hline No of Observations & 1.9441 & & \\
\hline
\end{tabular}

$* *$, * indicates $5 \%$, and $1 \%$ level of significance respectively.

Source: Calculated by author

176 

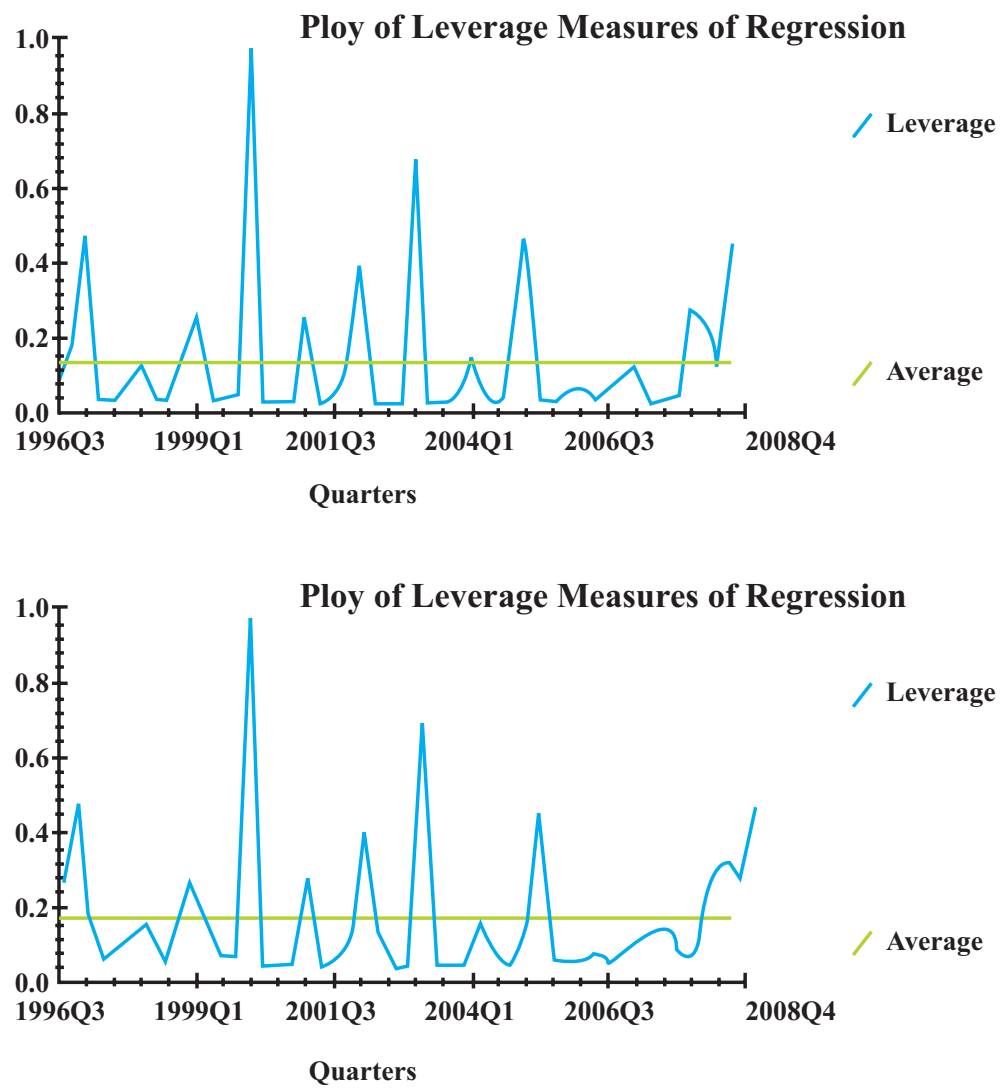

Plot of Cumulative Sum of Recursive Residuals

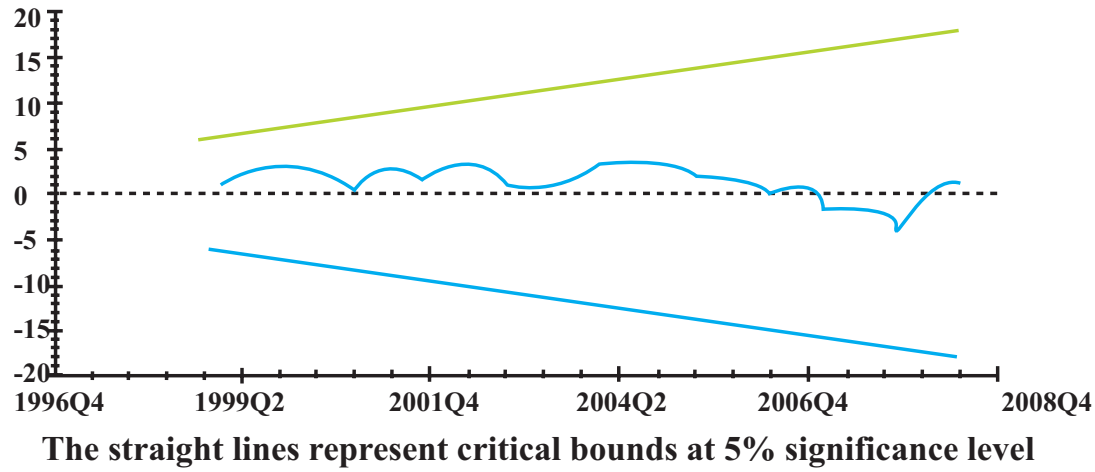


https://ir.iba.edu.pk/businessreview/vol5/iss2/11

DOI: https://doi.org/10.54784/1990-6587.1251

\section{Plot of Cumulative Sum of Recursive Residuals}

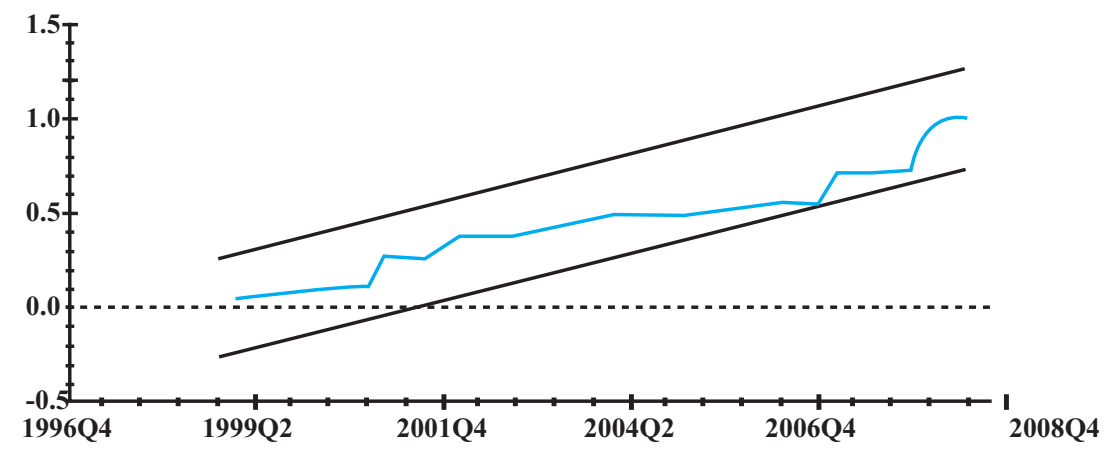

The straight lines represent critical bounds at $\mathbf{5 \%}$ significance level

\begin{tabular}{|c|c|c|c|}
\hline Independent variables & Measurement Code & $\begin{array}{c}\text { No. of } \\
\text { Questions }\end{array}$ & Hypothesis \\
\hline Reduce operating cost & $\begin{array}{l}\text { Capital investment } \\
\text { Overhead \& fixed cost } \\
\text { Space }\end{array}$ & $\begin{array}{l}5 \\
5 \\
5\end{array}$ & $\begin{array}{l}\text { H1a } \\
\text { H1b } \\
\text { H1c }\end{array}$ \\
\hline Improve company focus & $\begin{array}{l}\text { Focus on new product development } \\
\text { Explore new market segment }\end{array}$ & $\begin{array}{l}5 \\
5 \\
5\end{array}$ & $\begin{array}{l}\mathrm{H} 2 \mathrm{a} \\
\mathrm{H} 2 \mathrm{~b} \\
\mathrm{H} 2 \mathrm{c}\end{array}$ \\
\hline $\begin{array}{l}\text { Access to world class } \\
\text { capibility }\end{array}$ & $\begin{array}{l}\text { Available of specialist } \\
\text { Latest and high efficiency technology } \\
\text { Established tool and support infrastructure }\end{array}$ & $\begin{array}{l}5 \\
5 \\
5\end{array}$ & $\begin{array}{l}\mathrm{H} 3 \mathrm{a} \\
\mathrm{H} 3 \mathrm{~b} \\
\mathrm{H} 3 \mathrm{c}\end{array}$ \\
\hline $\begin{array}{l}\text { Unavailablity of internal } \\
\text { resources }\end{array}$ & $\begin{array}{l}\text { Limited production capacity and space } \\
\text { Lack of content expert and support } \\
\text { Infrastructure }\end{array}$ & $\begin{array}{l}5 \\
5\end{array}$ & $\begin{array}{l}\mathrm{H} 4 \mathrm{a} \\
\mathrm{H} 4 \mathrm{~b} \\
\mathrm{H} 4 \mathrm{c}\end{array}$ \\
\hline Dependent Variable & Description of measurement & \multicolumn{2}{|c|}{ Number of questions } \\
\hline Outsourcing Decision & Outsourcing Decision & \multicolumn{2}{|c|}{10} \\
\hline
\end{tabular}


https://ir.iba.edu.pk/businessreview/vol5/iss2/11

DOI: https://doi.org/10.54784/1990-6587.1251

Business Review - Volume 5 Number 2

July - December 2010

\begin{tabular}{|c|c|c|c|}
\hline Factors & Categories & Frequency & Percentage \\
\hline \multirow[t]{2}{*}{ Gender } & Male & 55 & 75.71 \\
\hline & Female & 17 & 24.29 \\
\hline \multirow[t]{4}{*}{$\overline{\text { Age }}$} & $21-30$ & 11 & 15.71 \\
\hline & $31-40$ & 40 & 57.14 \\
\hline & $41-50$ & 11 & 15.71 \\
\hline & More than 50 Years old & 08 & 11.43 \\
\hline \multirow[t]{3}{*}{ Education } & Diploma & 03 & 4.23 \\
\hline & Degree & 23 & 32.86 \\
\hline & Masters and Others & 36 & 51.43 \\
\hline \multirow[t]{4}{*}{ Occupation } & Non Management & 04 & 5.71 \\
\hline & \begin{tabular}{|l} 
Executive \\
\end{tabular} & 20 & 28.57 \\
\hline & Management & 42 & 60.00 \\
\hline & Professional and others & 04 & 5.71 \\
\hline \multirow[t]{4}{*}{ Years of work experience } & Less than 5 years & 05 & 7.14 \\
\hline & $5-10$ years & 43 & 61.43 \\
\hline & $11-15$ years & 16 & 22.86 \\
\hline & More than 15 years & 06 & 8.57 \\
\hline \multirow{3}{*}{$\begin{array}{l}\text { Duration of Company established } \\
\text { (Years) }\end{array}$} & Less tjam 5 years & 17 & 24.29 \\
\hline & $5-10$ years & 43 & 61.43 \\
\hline & More than 10 years & 10 & 14.29 \\
\hline \multirow{4}{*}{ No. of employees in the organization } & Less than 50 & 25 & 35.72 \\
\hline & $50-100$ & 25 & 35.72 \\
\hline & \begin{tabular}{|c|}
$101-500$ \\
\end{tabular} & 12 & 17.14 \\
\hline & More than 500 & 08 & 11.43 \\
\hline
\end{tabular}

\begin{tabular}{|l|c|c|c|}
\hline \multicolumn{1}{|c|}{ Variables } & Number of Items & Items Dropped & Cronbach Alpha \\
\hline Capital Investment & 5 & 1 & .657 \\
\hline Overhead and Fixed cost & 5 & 1 & .688 \\
\hline Space & 5 & 1 & .692 \\
\hline $\begin{array}{l}\text { Focus on New product Development and Explore } \\
\text { New Market Segment }\end{array}$ & 5 & - & .644 \\
\hline Availability of Specialist & 5 & - & .705 \\
\hline Latest Technology and High Efficiency & 5 & - & .674 \\
\hline Established Tool and Support Infrastructure & 5 & - & .699 \\
\hline Limited Production Capacity and Space & 5 & - & .686 \\
\hline $\begin{array}{l}\text { Lack of Technical Content Expert and Support } \\
\text { Infrastructure }\end{array}$ & 5 & - & .655 \\
\hline Outsourcing Decision & 10 & - & .720 \\
\hline
\end{tabular}


https://ir.iba.edu.pk/businessreview/vol5/iss2/11

DOI: https://doi.org/10.54784/1990-6587.1251

Business Review - Volume 5 Number 2

July - December 2010

\begin{tabular}{|l|r|r|c|}
\hline \multicolumn{1}{|c|}{ Factors } & Beta & T-Ratio & Sig. t \\
\hline Capital Investment & .150 & 1.865 & .86 \\
Overhead and fixed cost & .201 & 2.976 & .62 \\
Space & .224 & 1.985 & .52 \\
Focus on new product development & 5.734 & 7.971 & .000 \\
Availability of Specialist & -4.123 & -7.013 & .000 \\
Latest technology and high efficiency & -3.234 & -6.354 & .005 \\
Established tools and support infrastructure & -2.456 & -5.473 & .009 \\
Limited production capacity and space & .457 & 2.351 & .016 \\
Lack of technical content expert and support infrastructure & 3.846 & 5.897 & .003 \\
\hline \multicolumn{2}{|c|}{ R square $=66 \%$} \\
Curbin Watson $=1.768$ \\
Condition index $=29.345$ \\
\hline
\end{tabular}

180 